Mitteilungen der Österreichischen Geographischen Gesellschaft,

157. Jg. (Jahresband), Wien 2015, S. 29-49

\title{
Metropolitan Transition in East-Central Europe
}

\author{
Piotr Korcelli and Ewa Korcelli-OlejnicZaK, \\ both Warsaw [Warszawa]*
}

with 1 table in the text

\section{CONTENTS}

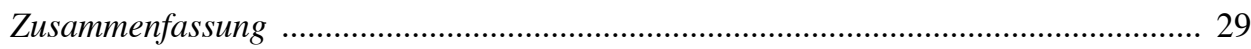

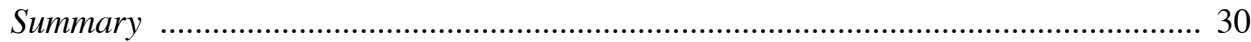

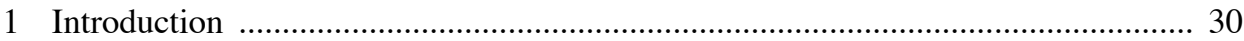

2 The making of metropolitan cities …................................................................. 32

3 The shaping of metropolitan areas ...................................................................... 34

4 The changing city-hinterland relations ............................................................ 36

5 The formation of inter-metropolitan networks .................................................. 37

6 The evolving structure of national settlement systems ........................................ 39

7 Metropolitan development in retrospect and prospect ........................................ 43

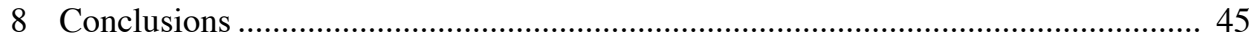

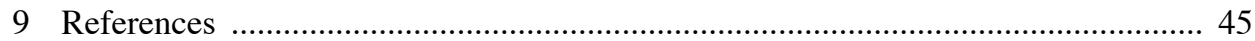

\section{Zusammenfassung}

Die Transformation der Metropolen in Ostmitteleuropa

Der Artikel untersucht und bewertet die jüngeren Tendenzen der Metropolenentwicklung in Ostmitteleuropa, indem er deren Merkmale auf verschiedenen Maßstabsebenen aufzeigt. Er betrachtet die derzeitige Transformation ausgewählter großer städtischer Zentren zu Metropolen, die Entwicklung von Metropolitanregionen wie auch die Entwicklung von Stadtregionen und zwischenstädtischen Beziehungen. Veränderungen der Siedlungsmuster und der Städtehierarchien werden im jeweiligen nationalen Rahmen in etwas größerer Genauigkeit diskutiert, wobei das Hauptaugenmerk auf der wachsenden Rolle der Hauptstädte liegt. Diese Trends werden vor einem konzeptionellen Hintergrund präsentiert und auch einigen früheren Prognosen über den Transformationsprozess der Me-

\footnotetext{
* Prof. Dr. hab. Piotr Korcelli and Assoc. Prof. Dr. hab. Ewa Korcelli-Olejniczak, Department of Spatial Organisation, and, Department of Urban and Population Studies, respectively, Polish Academy of Sciences, ul. Twarda 51/55, PL-00-818 Warsaw, Poland; email: korcelli@twarda.pan.pl; eko@twarda.pan.pl, http:// www.igipz.pan.pl
} 
tropolen gegenübergestellt. Schließlich wird auf einige ausgewählte, v.a. demographische Faktoren kurz eingegangen, die sehr wahrscheinlich auf die künftige Stadtentwicklung in der Region Einfluss nehmen werden.

Schlagwörter: Entwicklung der Metropolen, Siedlungssysteme, Hauptstädte, Stadt-Umland-Beziehungen, Ostmitteleuropa

\section{Summary}

The article examines and evaluates the recent course of metropolitan development in East-Central Europe by identifying its signs that appear at various levels of spatial scale. It looks into on-going transformation of selected large urban centres into metropolitan cities, the development of metropolitan areas as well as the evolving city-region and inter-urban relations. Changes in settlement patterns and urban hierarchy, which are observed at a national level, are discussed in somewhat greater detail with a focus put on the growing role performed by the capital cities. These trends are presented against a conceptual background and are also confronted with some earlier forecasts concerning the path of metropolitan transition. Finally, selected, in particular demographic factors that are likely to bear on future urban development in the region are briefly referred to.

Keywords: metropolitan development, settlement systems, capital cities, city-hinterland relations, East-Central Europe

\section{Introduction}

Metropolitan development, generally interpreted as a late phase of the urbanisation process, is defined and positioned on the time scale in different ways. J. BorCHERT (1967) following the classical study of R.D. MCKENZIE (1933), identified its appearance with rapidly growing human interaction in space in "the automobile, air travel, and amenity age", the era which started in the United States as early as the 1920s. ${ }^{1)}$ Conversely, in Europe (HALL 1993) the growing evidence of metropolisation phenomena is typically linked to the advancing globalisation and the transition from a goods processing to an information processing economy, the trends that have been marked especially since the 1970s.

East-Central Europe ${ }^{2)}$ became an active scene of the metropolisation process a few decades later following the onset of systemic transformation in 1989-1990. Although its

1) It coincided with the stage of metropolitan economy, the concept introduced by N.B.S. Gras (1922).

2) The region is here identified with those former Socialist countries that have become members of the European Union since 2004. It is often denoted in literature as Central and Eastern Europe, though the latter name may also refer to a much broader aggregate (see SoкоL 2001). Earlier, the term East-Central Europe was used so as to encompass a smaller set of countries - Poland, the Czech Republic, Slovakia and Hungary (see for example FASSMANN 1997). 
early symptoms, which were related to increasing spatial population mobility and included daily work commuting or the phenomenon of second homes, had started prior to that period, it is justifiable to link the metropolitan development in that part of Europe to the subsequent shifts from industry-dominated to services-based economy and to its gradual integration into the global economic circuit. With the arrival of the information age and owing to the intervening role of demographic change and the formation of the civil society (see VAN DER WUSTEN 1993) these processes have assumed a rapid, although considerably varying pace across the region.

In this article the signs of metropolitan transition as affecting cities and settlement systems in East-Central Europe are traced at several spatial resolution levels. At a local level they pertain to the process in which selected large urban centres can graduate into the category of metropolitan cities. At a sub-regional scale the development of metropolitan areas is documented with a focus on patterns of residential suburbanisation. At a regional scale changes in city-hinterland relations are shown in terms of a weakening of the earlier and/or the development of new functional ties. At a national and international level the question of increasing economic and social interaction involving both competition and co-operation between metropolitan centres is posed, together with prospects concerning the formation of inter-metropolitan networks. Finally, changes in the structure of national settlement systems are discussed and evaluated with an emphasis on patterns of spatial differentiation and the evolving urban hierarchy.

When illustrating the trends observed, we attempt to identify and discuss both these developments that may be denoted as more or less general characteristics of the metropolisation process as well as those which are rather specific to the area considered and can be largely attributed to its historical legacy. Since we hypothesise that metropolitan development, as proceeding in the region, basically represents a 'catching-up' process, i.e., a delayed development phase, some of its main traits are herewith confronted with those features that were earlier recognised and generalised in the form of research concepts referring to West European and North American cities. This overview and interpretation of trends and their underlying factors is conducted by drawing, rather selectively, on relevant literature sources (including some earlier work by the authors) as well as on recent statistical information, in particular the one provided within the framework of the European Spatial Planning Observation Network (ESPON) programme.

A particular aim of this paper is to confront the generalisations to be arrived at with some hypotheses and expectations, which were formulated approximately 20 years ago, i.e., at the initial phase of the process of systemic transformation in East-Central Europe, by such accomplished authors as Elisabeth LichtenBERGER (1994), Jiři MusiL (1993), György ENYEdi (1994) and Peter Hall (1990, 1993). Those early hypotheses on the growing role of capital cities, the changing urban built environment, the polarisation within urban systems, both in space and within urban hierarchy, or on inter-metropolitan competition are reflected upon in the final section. Also in that section some factors are identified that may bear on the future course of metropolitan development in the region. 


\section{The making of metropolitan cities}

Whereas the most, if not all the large urban centres aspire to the status of metropolitan cities, only some do succeed in gaining an international recognition in this respect. ${ }^{3)}$ This recognition, in addition to population size, is based on both physical criteria related to the built environment such as the presence of conspicuous urban design forms and advanced technical infrastructure as well as on functional elements, in particular the development of highly specialised economic activities, but also unique cultural and academic institutions with long range of influence, i.e., the metropolitan functions (see KNOX \& TAYLOR 1995). These criteria, however, tend to be considered within a broader, economic and political context and often assume a qualitative character.

Cities of East-Central Europe have been represented in the typologies of European metropolises, among others those elaborated by R. BRUNET (1989), N. CATTAN et al. (1994) as well as P. TREUnER \& M. FouCHER (1994) since the beginning of the systemic transformation period, although they were in some instances identified as potential or prospective metropolitan centres. Since that time, the major cities in the region have experienced an extensive both physical and functional change, only partly reflected by their more recent international rankings. ${ }^{4)}$

The functional structure of large cities has undergone particularly rapid adjustments as a consequence of privatisation, currency reforms, the entry of foreign capital and the opening of domestic markets to globally acting economic forces. Massive industrial restructuring was perhaps the most notable phenomenon in the early phase of the transformation process. The share of industry and construction, which had accounted for $48.8 \%$ of total employment in Budapest, $43.1 \%$ in Warsaw [Warszawa] and $42.4 \%$ in Prague [Praha] in 1978 fell down to typically less than $20 \%$ by the year 2000 . (It has stabilised since then.) At that time, the employment composition in East-Central Europe's capital cities already roughly converged to West European standards. ${ }^{5)}$ Their integration into world markets has brought along a significant presence of global firms (see for example DövENYI \& KovÁcs 2006) including those in the advanced producer sector - the development which has been thoroughly documented in the Global and World City (GaWC) Research Network studies (TAYLOR et al. 2012).

\footnotetext{
3) At a national and regional level more liberal criteria are often used. For example, in Poland's Concept of National Spatial Development (Ministry of Regional Development 2012) ten cities are identified as metropolitan centres, while the Union of Polish Metropolitan Cities is comprised of twelve members.

4) More recently, comprehensive work in this domain is attributed to the ESPON programme, in particular ESPON 1.1.1 (2004) and ESPON 1.4.3 (2007) projects, the results of which are still regarded as setting standards in the field by both planners and academics. Within the set of 76 Metropolitan European Growth Areas (MEGA), which were identified in the framework of the former project, the region of East-Central Europe was represented by 18 MEGA (including all national capitals by definition), even though these were predominantly allocated into the lowest (fourth) class. Among the 70 Metropolitan Urbanised Areas (MUA) selected, mainly on the bases of morphological criteria for the purpose of ESPON 1.4.3 project, the transnational Silesian-Moravian MUA was classified as the sixth-largest in the EU in terms of population size.

5) This change is documented, among other sources, in a comparative study on metropolitan functions of Berlin and Warsaw (KoRCelli-OlejNICZAK 2012a).
} 
The development of the new economy with its focus on the service sector has been matched by a gradual conversion of physical urban patterns. Concerning this area the predictions of P. HALL (1993, p. 885), who in the case of national capitals as well as selected major provincial cities in the region anticipated "an unprecedented rate of reconstruction", have largely materialised. This is expressed by a high dynamics of housing construction as well as a rapid expansion of new commercial facilities. Recent growth of Warsaw's housing market may serve as an illustration of the trends. The demand based on housing shortage inherited from the past, the raising household incomes, the development of mortgage credit market as well as in-migration (mostly from smaller urban places, often accompanied by transfer of savings) were among the factors responsible for the increase of the city's housing stock by nearly 30\% between 2000 and 2011 with 170,464 dwelling units built during that period - less than in Madrid and London, but more than in any other city within the European Union (EU). Also Budapest and Prague with 89,901 and 65,546 new units, respectively, had impressive records in this respect (MENDEL 2013). New office space has also been added at high rates; in the case of Warsaw its volume has exceeded 4 million square meters by 2013 (up by 1.5 million since 2008) and, as attested by the on-going construction activity, still fails to meet the present demand.

Against these new development trends metropolitan cities in East-Central Europe continue to face numerous challenges related to their recent as well as more distant past. Among such specific issues are pending property restitution claims as well as the needs to modernise the relatively new, yet technically, economically and also socially outdated housing stock from the 1950-1990 period.)

An important factor of the development of metropolitan cities in the region was the restoration of local government autonomy, which awoke the awareness of the value of public space and hence of citizens' responsibility for the local milieu (MARSZA£ 2008). At the same time, however, it has generated inter-municipal and inter-district competition, which often precludes any co-operative ventures. On the whole, however, it has led to an outburst of local pro-development initiatives, the type of policies which are referred to by P. HALl (1993) as "promotion and boosterism".

Perhaps a model pattern of long-term, multifaceted pro-metropolitan policies based upon supra-local co-operative engagement is represented by the case of the Upper Silesian conurbation. This large urbanised area, once considered the economic heartland of Poland, was most negatively affected by the rapid shrinkage of its economic base, i.e., coal and steel industries in the 1990s. The subsequent partial re-industrialisation was not a sufficient remedy for the area's complicated problems, which, aside from economic and social issues include a poor state of both natural and man-made environment. In an attempt to address this situation efforts were undertaken at three interrelated planes. First of all the

\footnotetext{
6) Questions related to social aspects of housing are extensively covered in recent literature, which is frequently referring to the concepts of the post-Socialist city (Tosics 2005; Sykora \& BouZArovsKy 2011; WęClawOwicZ 2013). Among more specific themes problems of housing privatisation, modernisation of pre-fabricated units, demise of social housing construction and the development of gated housing estates (see HIRT 2012) are the ones that receive special attention.
} 
establishment in 2007 of the Upper-Silesian Metropolitan Union [Górnośląski Związek Metropolitalny $]^{7)}$ created an institutional platform for inter-municipal cooperation in the field of urban management and infrastructural investments.

The second project, founded upon a network of research, academic and cultural institutions active in the area aims at the development of the creative industry sector, a seed-bed for the ultimate re-orientation of the region's economy towards knowledge-based activities (KLASIK, BinIECKI \& OCHOJSKi 2014).

The third major effort, so far only partially accomplished, is to up-grade the metropolitan core area by constructing in Katowice an imposing civic centre together with a new academic complex (see SARZYŃSKI 2014).

The transformation of East-Central Europe's large urban centres, their adoption of what is regarded as metropolitan standards has been aided by a host of factors, among which the process of European integration is certainly of primary importance. Still, their recent functional change, in particular, cannot be considered to be completed. Owing to the nature (as well as the timing) of economic restructuring, cities in East-Central Europe lag behind in the development of at least two major categories of metropolitan functions (for which they also compete against each other), namely, high-tech industries and international corporate control functions (ESPON 2004, 2007; GÁL 2015). This structural gap is likely to bear on their positioning among the European metropolitan centres in a long term. ${ }^{8}$

\section{The shaping of metropolitan areas}

Spatial development of metropolitan areas is typically depicted by referring to the concept of stages of urban development or city life cycles (VAN DEN BERG et al. 1982; HALL \& HAY 1980), according to which this process consists of successive stages of urbanisation (concentration), suburbanisation (de-concentration), des-urbanisation (dispersion) and re-urbanisation (re-concentration). The third development stage, which is also indicated as counter-urbanisation (BERRY 1978), may sometimes be identified with the phenomenon of peri-urbanisation (PIORR, RAVETZ \& Tosics 2011). The causal background of the development transition is found in urban land rent theory (ALONso 1964), and the metropolitan area is usually identified with the daily urban system (BERRY 1973). Although suburbanisation is mainly interpreted in terms of residential movement, this process is closely interconnected with de-concentration of commercial and industrial activities, even though more specific locational rules are applicable for each of these sectors. Such rules tend also to change over time (see STANILOv 2003).

\footnotetext{
7) The Union extends over a contiguous urbanised territory and consists of 14 member cities ranging in size between 53,000 (Świętochłowice) and 309,000 (Katowice - the main urban centre). The total population is 2 mio. approximately.

8) Z. GÁL (2015) identifies the competition between East-Central European capital cities among factors responsible for the failure to achieve the status of international financial centre by Budapest.
} 
In East-Central Europe, trends towards de-concentration of population and economic activity from urban cores to the surrounding zones were rather weak under the centrally planned economy. De-concentration phenomena, when identified, were usually attributable to state-controlled, industrial location and urban growth limitation policies (KoRCELLI 1990, 2005). So was the origin of large polycentric urban forms, referred to as urban or urban-industrial agglomerations. ${ }^{9)}$ Spatial concentration forces were generally found to prevail at sub-regional scale until the late 1980s at least. Since that time, urban de-concentration stemming from growing spatial population mobility and governed by locational preferences and market rules concerning land values has been affecting cities of various size and functional type. The cities have entered, in light of the concepts discussed, the suburban development stage.

While in Europe as a whole contemporary suburbanisation processes tend to assume the features of urban sprawl (Coutch, LeOntidou \& Petschel-Held 2007), such an evaluation certainly holds with respect to suburban development patterns within the region (see, e.g., GUTRY-KORYCKA 2005). Environmental conflicts, caused by inter-mixing of residential with commercial and industrial land use are especially visible around the large urban centres (see DöVENYI \& KovÁcs 2006; GrochowsKi 2012). These problems may be largely attributed to the prevailing practice of spatial planning and land-use management, which is characterised by insufficient both vertical and horizontal co-ordination, missing co-operation between local governments and priority given to short-term objectives.

With infrastructural investment typically lagging behind the often dispersed residential development and the latter's tendency to encroach upon environmentally valuable areas, land use conflicts tend to be inevitable. At the same time, the dynamic and uncontrolled nature of suburbanisation trends needs to be interpreted as a social phenomenon, namely a reaction to generally inadequate housing conditions prevailing within cities, to dwelling standards which were inherited from the past.

Concerning the impacts of suburbanisation phenomena upon existing settlement patterns the case of Bratislava seems to provide a suitable illustration of trends observed (see SLAVIK et al. 2011). Following the results of the study the incipient phase of suburbanisation begun in the functional region of Slovakia's capital in 1992, when local administrative units in the surroundings of Bratislava started to grow in population numbers. The increase, relatively small during the 1990 s, has notably accelerated during the next decade. A turning point in the process was the year 1997, when a substantial population decrease occurred in the city. Within the suburban zone the fastest growth has been taking place in those areas that are considered as environmentally attractive. Conversely, the anticipated growth of satellite towns situated in the vicinity of the city has not materialised. Among the suburbanites 30 to $40 \%$ were former Bratislava residents with the proportion being even higher in the case of particularly attractive areas. On the basis of field observations and interviews with local officials the authors conclude that the actual magnitude of popu-

9) Transformation of an urban agglomeration into a metropolitan area based on the case of Łódż was described by S. LisZEWSKi (2010). 
lation redistribution in the Bratislava region was over the period of 2000-2009 actually by approximately one-third larger than what the public statistical sources revealed. ${ }^{10)}$

As noted earlier, the spontaneous suburbanisation phenomena have brought along a number of planning and policy issues to cope with, a task for which the new local government institutions are insufficiently equipped. In addition to environmental hazards already alluded to, these include questions related to taxation, public transport, education, etc. In this context, initiatives to introduce the metropolitan-level government (including the proposed Metropolitan Law in Poland) may be referred to. Under the prevailing liberal approaches, however, such attempts have so far limited chances to succeed.

\section{The changing city-hinterland relations}

At the regional level the metropolisation processes are generally reflected by an expanding market range of large cities and their increasing functional dominance over the remaining settlement components, the lower-order service centres in particular. Metropolitan regions become a major dimension in spatial organisation of urbanised societies (Duncan et al. 1960; BerRy \& HorTon 1970).

Over time, there is a growth of interaction among metropolitan centres (first of all in the form of information flows), a consequence of the emergence and development of new, specialised functions. These are the functions for which such centres constitute the natural realm (PRED 1975). The city-hinterland relations, while continuing to play an important role on account of material flows (BouRne 1975), become gradually overshadowed by the expanding inter-metropolitan linkages. This trend is often interpreted in terms of a detachment of metropolitan centres from their regional surroundings. Metropolitan cities, however, continue to perform the role of focal points for highly specialised services and transport linkages at a regional level, even if they no longer constitute primary markets for hinterland-produced goods. Still, various types of metropolis-region relations as well as different patterns of spatial and functional organisation of metropolitan regions can be identified (KorCELli-OleJNICZAK 2012b).

In East-Central Europe some phenomena that presaged the formation of metropolitan regions appeared long before the systemic transformation period. In fact, the role of large cities as nodal points in focusing economic and social linkages at both regional and national level was well documented in scientific literature (see, e.g., EBERHARDT 1970). Many of these linkages, however, were discontinued in the 1990s as a result of closures of industrial branch plants located in smaller urban places, a decline of internal migration and of long-distance commuting to work as well as the substitution of imported for locally produced goods. The regional settlement systems were undergoing internal polarisation (CZYŻ 1998). Along with a gradual adaptation of large, multifunctional cities to open mar-

\footnotetext{
${ }^{10)}$ A specific feature of the suburbanisation phenomenon is in the case of Bratislava its trans-border range extending in particular to the neighbouring municipalities in Hungary and, to a smaller extent, in Austria (SLAVIK et al. 2011, pp. 52-53).
} 
ket economy, there was a shrinkage of the economic base of industrial centres of various size, also due to a concentration of specialised production and service activities in the emerging metropolitan areas. The new patterns of city-region linkages tend to be focused around a more limited than in the past number of not only large, but also economically viable metropolitan centres. ${ }^{11)}$

In empirical studies on changing city-hinterland relations (GoRZELAK \& SMĘTKOWSKI 2005) an unbalanced character of their mutual links is revealed. This takes forms of backwash effects and the appearance of socio-economic shadow zones, typically within the radius of approximately 50-100 kilometers from major urban centres. As the findings of ESPON FOCI (2010) show, intra-regional socio-economic disparities are particularly marked in the case of East-Central Europe's metropolitan regions. Such disparities are generally expected to persist in the future, although their intensity, when measured by Gross Domestic Product (GDP) per capita differentials, tends in the case of some capital city regions to diminish since the beginning of the economic crisis in 2008 (see SMĘTKOWSKI 2015).

Whereas the development of large cities becomes increasingly dependent upon the position such cities hold within broader, inter-urban and inter-metropolitan networks, some characteristics of their regional surroundings may also play an important role in this respect. This pertains in particular to environmental assets of the hinterland zones, on the basis of which new functions of regional range and new kinds of city-region relations can be generated. It is still to be seen, if these relations evolve as in other parts of Europe towards a greater functional complementarity.

\section{The formation of inter-metropolitan networks}

As pointed out above, in conceptual terms the growing interaction among metropolitan centres reflects their intensifying functional complexity and the increasing role of information flows as opposed to material flows within urban systems (CASTELLS 2000). It is also an indicator of the systems' integration.

Within the spatial policy domain, the development of inter-metropolitan networks is seen as a means of supporting the competitiveness of individual urban centres at a national level as well as a way to enhance the international performance of broader urban systems. ${ }^{12)}$ Such policies are executed, first of all, via infrastructural investments, i.e., by constructing and up-grading the inter-metropolitan, supra-regional road and rail systems.

\footnotetext{
${ }^{11)}$ On this point see also I. IANoş (2002, p. 301), who foresees that regional subsystems gravitating around Romania's six major cities will become more defined in the coming years.

12) This approach has explicitly been followed in the recently elaborated Concept of Spatial Development of Poland (Ministry of Regional Development 2012), which formulates conditions for an increase of functional interdependence among the nation's six major metropolitan centres.
} 
Their side effects include a reorganisation of spatial accessibility patterns with subsequent changes in functions of urban and rural areas along the transportation corridors.

Although there is a growing empirical evidence on inter-urban including inter-metropolitan interaction that pertains to East-Central Europe, it does not allow us to formulate straightforward generalisations at this point. This is due in particular to a scarcity of relevant cross-temporal studies. It is worthwhile, however, to refer to the recent work on this theme.

As to present state, H. KRAMAR \& J. KADI (2013) have shown that the distribution of firms in the advanced producer sector suggests the existence of active mutual functional ties between Budapest, Prague, Vienna [Wien] and Warsaw with the position of Berlin as home of firm subsidiaries of a higher market range. In real terms, however, economic linkages such as trade flows within the region including interactions among the capital cities are relatively weak, which reflects the general re-orientation of the respective national economic systems towards Western Europe after 1990. More specifically, this situation is related to the strong position of multinational firms in national economies (and, in particular, in functional profiles of the large cities) as well as a low propensity on the part of domestic enterprises, due to their dependence upon external capital and know-how, to invest on foreign markets (Di LELlo \& RozENBLAT 2014). This is also somehow connected with a creeping development of modern, cross-border transportation infrastructure interlinking the main urban centres in the region. ${ }^{13)}$

At a national level the dominant position in interurban functional networks held by capital cities appears to be unchallenged. A detailed analysis of functional ties between Poland's ten major urban centres (KOMORNICKI \& SıŁKA 2011) has revealed a high concentration of linkages in the capital city, over-proportional when compared to Warsaw's overall economic and demographic potential. Warsaw also serves as the main hub within international linkage networks. Among other cities, only four - Cracow [Kraków], Poznań, Wrocław and Gdańsk-Gdynia maintain relatively strong functional links, both with each other and in relation to the remaining urban centres. Their main international linkages such as Poznań - Berlin, Cracow - Vienna or Gdańsk - Stockholm are focused upon selected metropolitan cities in the neighbouring countries, typically across the former East-West division line in Europe.

A picture that comes out of this brief account proves that the presence of multinational firms alone does not necessarily lead to the formation of inter-urban functional networks both within individual as well as between neighbouring countries, since business strategies of such firms are usually global rather than regionally focused. This also points to an earlier observation on underperformance of metropolitan cities of East-Central Europe in the area of corporate control functions of international range. In this context, one should agree with O. Di Lello \& C. Rozenblat (2014), when they conclude that the entry by these

\footnotetext{
${ }^{13)}$ Such infrastructural gaps are not a real obstacle to the emergence of international research networks in the region. In fact, the role of academic and research institutions in the development of inter-urban linkages in Europe seems to be particularly important (see Groth \& AlvHeiм 2001).
} 
urban centres into balanced intense interactions with major European and global metropolises still remains a question of time.

\section{The evolving structure of national settlement systems}

When inspected from the national level, human settlement systems display high inertia as expressed, among others, by the stability of city rank-size distributions over time (Pumain 2000). Nonetheless, in the case of East-Central Europe notable changes can be observed in both spatial settlement patterns and urban hierarchy during the last two and a half decades, i.e. a relatively short time span.

The rural areas have been particularly affected by the metropolisation processes, which is reflected in their progressing differentiation into various categories. ${ }^{14)}$ In situ urbanisation, manifested by a massive retreat from farming occupations, has become a widespread phenomenon. At the same time extensive, predominantly agricultural areas witness a thinning-out of the settlement tissue, together with an advanced population ageing. The perception of rural areas as new consumption spaces (ESPON 2013) is still rather rare and rural gentrification tends to be mainly restricted to environmentally attractive prime recreational areas.

As some authors claim (see DoMAŃSKI 2008), the traditional urban-rural dichotomy has been replaced by the division into metropolitan and non-metropolitan areas, which nowadays constitutes the main dimension of socio-economic differentiation in space. ${ }^{15}$ This also implies that the percentage of urban population should no longer be referred to as an adequate indicator of the urbanisation level. ${ }^{16)}$ In fact, a number, if not the majority of suburban communities hold the administrative status of rural areas.

Since the category of non-metropolitan areas (or non-metropolitan regions) tends to be strongly differentiated internally, it is usually further subdivided for analytical purposes. In a study on sources of economic growth in East-Central Europe in the years 2000-2008, M. SMĘTKOWSKI (2013), in addition to metropolitan area ${ }^{17)}$, distinguished the categories of peripheral as well as of transitional areas, the latter including, among others, the so-called old industrial districts. Since the period under analysis was one of general economic expansion, growth was found to prevail in all types of regions. Its sources, however, varied.

14) K. HeFFnER (2014) distinguishes three categories of rural territories: integrated, intermediate and remote rural areas. The first type comprises peri-urban areas that display population growth, intensive mobility patterns and rapid land use change. Areas of the second type, which are interspersed with local town networks and recreational centres, are dominated by market-oriented agriculture. The third type includes rural problem areas with marginal farming, derelict land use and social dysfunctions (see also VAISHAR 2008).

${ }^{15)}$ An alternative approach is to perceive socio-economic differentiation of national territories in terms of the division into metropolitan and non-metropolitan regions. In fact, the metropolisation process may be regarded as the main direct factor responsible for the growing interregional socio-economic disparities.

16) In Poland the official urbanisation rate decreased from 62.1 to $61.7 \%$ between 1991 and 2010, while an internationally comparable share of urban population is estimated to fall within the range of $70-72 \%$. In Slovakia the urbanisation level is reported to have decreased from 56.8 to $54.7 \%$ during the same period.

${ }^{17)}$ These areas consist of single NUTS-3 units or their aggregates and are referred to as regions. 20 metropolitan regions were identified in East-Central Europe for the purpose of the study. 
While the transitional areas noted some re-industrialisation trends and an improvement of economic indicators in the peripheral areas was related to a modernisation of the agricultural sector, in the case of metropolitan areas it was mainly attributable to an extension and upgrading of producer-service activities. Thus, as the above as well as other studies demonstrate, the metropolitan areas, the unquestionable leaders of socio-economic transformation during its early phase (see FASSMANN 1997), have continued to stay ahead at a later stage of development in the process of structural change stimulated by EU accession.

Aside from following the area-type based perspective one might now turn to questions concerning the way in which the metropolisation process is reflected by the changing position of and relations between cities of various size and functional profile. In this case, in addition to metropolitan cities, one should also consider the categories of secondary large centres, the middle-sized cities as well as small towns.

When searching for general trends in this domain, it is necessary to take into account the inherited structural properties of individual national settlement systems with the degree of the systems' polycentricity, both morphological and functional (ESPON 2004; BURGER \& MEIJERS 2012), being an obvious point of departure. Here reference is made mainly to the former concept, i.e., regularities pertaining to the size structure and spacing of urban places over a national territory. In this respect, national urban systems in East-Central Europe vary considerably - from explicitly polycentric in Poland via moderately polycentric in the Czech Republic and Romania to monocentric with a dominant role of the capital city as in the case of Hungary or Latvia (KRIŚJANE 2001). Distortions from regular hierarchical patterns can occur at different spatial levels as illustrated in the case of Romania: "If one compares the capital city to the remainder of the Romanian urban system, there are two distinct sections in the hierarchy. One section contains a number of undersized cities that are obviously lagging behind, while the intermediately sized cities appear to be relatively oversized. The latter is clearly the result of [... (the growth)...] that occurred in county-seats and certain specialized industrial centres after 1968. The remainder of the hierarchy consists of a relatively low number of small towns that appear undersized [...]. If there were more small rural towns, the hierarchy would have appeared more balanced." (IANOş 2002, p. 300)

Such distortions, which are related to different preconditions including delayed urbanisation processes, can in the case of East-Central Europe be also attributed to policies conducted during the state-Socialism period. Their effects were in fact far from equivocal. While aiming in principle at territorially balanced development, these policies were restricted by sectorally determined priorities. The large city growth was subject to administrative controls pertaining to domicile registration and employment quota, but it was at the same time spurred by the expansion of the industrial base and the concentration of political power. As a result, when measured by the evolution of city-size distribution, national settlement systems in East-Central Europe were becoming more concentrated over time. The highest rates of growth were nevertheless experienced by medium-sized as well as medium-to-large rather than the largest urban centres (KoRCELLI 1990).

Against these earlier trends with their political and socio-economic context, the major contemporary phenomenon, which appears to be shared by all countries of the region, is an over-proportionate development of capital cities. Their role has been fostered irrespec- 
tive of the initial position (be it primate or challenged by other urban centres) within national settlement systems. ${ }^{18)}$ They contribute with substantial shares to the national Gross Domestic Products (GDPs). ${ }^{19)}$ They are conventionally referred to as metropolitan centres and perceived so as to form nodal points of the emerging European urban system.

At least four kinds of factors have contributed to this development. The first among these refers to the nature of the metropolisation process per se. With a few exceptions it is all over Europe that 'the capitals are taking the lead' as this trend conforms to the locational logic of the modern service-sector-dominated economy (GROTH 2001; ESPON 2013). Secondly, while under centrally planned economies the capital cities were growing on account of the burgeoning state bureaucracy, their development was at the same time restrained down to lower than 'normal' rates by industrial deconcentration policies as well as other explicit growth limitation measures (KoRCELLI 1990). The present-time expansion under the open market economy and the liberal spatial policy regime can therefore be interpreted as a compensatory development phase. The third factor refers to the post-1989 systemic transformation period, when capital cities in East-Central Europe, perceived as minimum-risk locations, were performing the main gateway functions for inward foreign investment flows (FASSMANN 1997). Finally, new growth stimuli associated with the EU membership include major infrastructure development, an extension of institutions in the public sphere, together with all associated multiplier effects in the private economy.

The category of secondary large urban centres includes a set of some 25 cities with population numbers in the range of approximately 300-600,000 (see Table 1). It basically corresponds to the second level in national urban hierarchies, one step below the capital city level, although in some smaller countries in the region cities of that size are missing. Among these centres at least several are recognised as metropolitan cities in national planning documents as well as in some international studies (see ESPON 2004, 2007). In general their position within national urban systems has been fostered during the last 20-25 years. These cities have generally succeeded to transform and differentiate their economic profile by attracting external capital developing the service sector and improving local infrastructure. Their sustained role is to a large degree based also on academic traditions and cultural functions (HoRvÁTH 2009) as some of them still perform the role of gravity centres of historical provinces (IANOŞ 2002). In the view of spatial development strategies, some among these cities may form functionally integrated bi-polar systems with respective national capitals (see the case of Kaunas; VAnAGas \& Staniunas 2001). A more complicated situation pertains to those large urbanised areas founded upon a heavy industry base such as the Upper Silesian conurbation and the agglomeration of Ostrava, which have been un-

\footnotetext{
18) This is true, even if some national capital cities in the region, for example Riga [Riga], have experienced declining population numbers and net migration losses. It may also be of interest to refer in this context to the somewhat specific case of Tallinn, the hinterland of which has undergone a contraction following the restoration of Estonia's independence in 1991 (TAMMARU 2000).

19) These are typically at least twice as large as their respective share in the total population - $13 \%$ in the case of Warsaw and $56 \%$ in Riga. Similar proportions pertain to other economic indicators. For example, the city of Warsaw with its 1.7 million inhabitants (4.5\% of the national total) accounted for $10.6 \%$ of the total number of dwelling units built in Poland in the period of 1995-2011 (MENDEL 2013).
} 


\begin{tabular}{|c|c|c|c|}
\hline \multirow[t]{2}{*}{ Country } & \multirow[t]{2}{*}{ City } & \multicolumn{2}{|c|}{ Population size (000') } \\
\hline & & $\begin{array}{l}\text { Functional } \\
\text { urban area }\end{array}$ & $\begin{array}{c}\text { Morphological } \\
\text { urban area }\end{array}$ \\
\hline \multirow[t]{2}{*}{ Bulgaria } & Plovdiv & 415 & 341 \\
\hline & Varna & 362 & 322 \\
\hline \multirow[t]{3}{*}{ Czech Republic } & Ostrava & 983 & 365 \\
\hline & Brno & 535 & 376 \\
\hline & Plzeň & 352 & 165 \\
\hline \multirow[t]{2}{*}{ Hungary } & Debrecen & 297 & 209 \\
\hline & Miskolc & 283 & 184 \\
\hline Lithuania & Kaunas & 513 & 379 \\
\hline \multirow[t]{10}{*}{ Poland } & Katowice & . & 311 \\
\hline & (Upper Silesian Conurbation) & 3,029 & 2,279 \\
\hline & Łódź & 1,165 & 919 \\
\hline & Kraków & 1,236 & 807 \\
\hline & Gdańsk-Gdynia & 983 & 829 \\
\hline & Wrocław & 861 & 634 \\
\hline & Poznań & 919 & 679 \\
\hline & Szczecin & 610 & 416 \\
\hline & Bydgoszcz & 485 & 383 \\
\hline & Lublin & 451 & 354 \\
\hline \multirow[t]{7}{*}{ Romania } & Constanța & 364 & 364 \\
\hline & Iaşi & 349 & 349 \\
\hline & Cluj-Napoca & 332 & 332 \\
\hline & Timişoara & 328 & 328 \\
\hline & Galați & 325 & 325 \\
\hline & Craiova & 311 & 311 \\
\hline & Braşov & 307 & 307 \\
\hline Slovakia & Košice & 343 & 239 \\
\hline
\end{tabular}

Source: ESPON 1.4.3 (2007), with adjustments

Tab. 1: Secondary large urban centres in East-Central Europe

dergoing a critical process of industrial restructuring and at the same time facing multiple development problems related to environmental hazards and urban redevelopment.

The medium-sized and small towns, generally regarded as losers of the systemic transformation, are subject to a strong polarisation process. As pointed out earlier, the former category was the one that grew the fastest during the state-Socialism period, mainly as a 
result of industrial location policies of that time. A number of these urban places witnessed an erosion of their economic base during the 1990s followed by a selective partial recovery connected with new commercial as well as industrial activities. In general, however, their position within national settlement systems tends to decline. ${ }^{20)}$

Small towns, local service centres in particular, have a longer history of gradual contraction. This trend has become even more articulated during recent decades. It is especially pronounced in case of regions that form national peripheries and are typically affected by depopulation phenomena (HEFFNER 2008). The position of those among small urban places that perform specialised functions based on the utilisation of local, endogenous resources tends to be more stable, though it also strongly depends upon a broader regional context.

In general, concentration of economic activity in large cities and their functional areas is a clear manifestation of the advancing metropolisation process in East-Central Europe. ${ }^{21)}$ This does not imply, however, that functional integration of urban systems is a complete process under the present economic order. Spatial effects of the on-going change include an increasing dominance of capital cities in national urban hierarchies, persistence of socio-economic disparities in space, both inter- and intraregional, i.e., between metropolitan and non-metropolitan areas, internal polarisation of rural areas and a shrinkage of local settlement networks in peripheral regions. These spatial tendencies, strongly articulated during the 1990s, have since then been mitigated to some extent owing to overall socio-economic development with 'smoothing' effects of public infrastructural investments strongly supported by EU structural funds. It remains an open question, if these trends may be extended so as to signify a more-or-less permanent spatial and functional cleavage within the settlement systems or, alternatively, whether they represent a kind of transitional development phase to be followed by more sustainable, spatially balanced development patterns.

\section{Metropolitan development in retrospect and prospect}

Looking back at changes that have occurred during the last decades it is justifiable to observe that they basically correspond to those anticipated some 20 years ago by the scientific experts earlier referred to. This relates both to the growing (though only in the case of some smaller countries truly monopolistic) position of capital cities, the tendency that was accentuated by E. LiCHTENBERGER (1994), a high intensity of redevelopment of major urban centres (HALL 1990, 1993) as well as to polarisation trends within urban systems - those that were forecasted by J. Musil (1993) and include an increasing dependence of individual cities on their endogenous resources as well as the declining functions of

\footnotetext{
${ }^{20)}$ In some instances their situation was further impaired as a consequence of territorial reforms. In Poland 31 middle-sized towns lost the functions of regional (voivodship [województwo]) capitals following the administrative reform of 1999.

${ }^{21)}$ Such a trend is also observed in the case of spatial population redistribution, even though it fails to be fully documented in official statistics.
} 
numerous medium-sized and small towns. Such a conclusion also concerns the general direction of urban change in East-Central Europe, which, as perceived by Gy. ENYEDI (1994), follows with some time lag the general path of metropolitan development. All these predictions and hypotheses, while based upon the knowledge of local conditions, were at the same time well-rooted in urban development theory.

Against these findings, one should attempt to identify some factors and preconditions that may determine the future course of metropolitan development in East-Central Europe against the mainstream of European development (see KorCELLI-OlEJNICZAK \& KorCELLI 2015). Here we restrict the discussion to three, to some extent mutually countervailing factors, two among which refer to future population change. ${ }^{22)}$

The first factor pertains to structural properties of settlement systems, in particular the position of medium-sized towns, those that gained the status of new industrial centres during the state-Socialism period. These towns account for notable shares of the total population and comprise the layer of urban hierarchy that is most vulnerable to external pressure. Unless their functional profile is transformed so as to account for the increasing importance of knowledge-intensive activities, such urban places will likely continue in their present role as locations for price-competition-oriented industries and human-capital exporters and hence contribute to the observed polarisation of space into metropolitan and non-metropolitan areas. This would also imply that prospects for a cohesive spatial development at the urban system level are to be postponed further into the future.

The second factor concerns the role of demographic development per se. According to current population projections (see Wittgenstein Centre for Demography and GloBAL Human CAPITAL et al. 2012) most countries in the region (all except Slovenia and the Czech Republic) face a population decrease as well as a rather rapid process of population ageing during the next decades. Due to its negative impact on spatial population mobility this factor may work so as to diminish the rate of urban change and hence to stabilise the present settlement structure.

The third factor is related to future patterns of international migration. Until now its balance is strongly negative for East-Central Europe owing mainly to intra-EU migration flows. While this movement is likely to slow down considerably in the future, Europe as a whole will certainly be (as it already is) exposed to the growing pressure of immigration from third countries. The question arises to what an extent are cities in the region, in particular the large ones going to be involved in this process. If it becomes a major phenomenon, then these cities will be exposed to yet another dimension of contemporary metropolisation processes with a growing ethnic diversity and the accompanying polarisation of urban social space.

\footnotetext{
22) Identification of future urbanisation patterns in Europe is a task of large-scale policy-oriented research projects (see ESPON ET 2050 2012). In this article it is attempted to outline briefly those development factors that seem to be specific to the region.
} 


\section{Conclusions}

Over the last two decades the countries of East-Central Europe have been undergoing a rapid metropolitan transition. It is a delayed, yet a dynamic process with some general and some specific characteristics. This change is manifested first of all in the physical and functional transformation of large cities, which have become primary beneficiaries of the new economic and political system. It is also expressed in the form of accompanying phenomena - the suburbanisation movement, the polarisation of socio-economic space into metropolitan and non-metropolitan areas and the accelerating depopulation of peripheral rural areas. At a national level the evolution of urban hierarchy entails an increasing dominance of capital cities with a relatively stable position of other large urban centres. Parallel trends observed include a diminishing importance of medium-sized towns, mono-functional industrial centres in particular, and both functionally and regionally dependent differentiation of the category of small towns involving a persistent decline of their role as local service centres.

The late arrival of metropolisation phenomena in East-Central Europe together with its historical legacy is reflected by an incomplete structure of metropolitan functions of the major urban centres, a still deficient functional integration of national urban systems, a largely uncontrolled suburban development, persisting socio-economic disparities between cities and their hinterland zones, diverging patterns of change in places situated at different urban hierarchy levels. At the same time these trends are accompanied by a progressing physical as well as functional modernisation of both urban and rural areas, the change that has markedly accelerated during the EU membership period. While the scope and intensity of all these phenomena vary among individual countries due to differences in the structure of settlement systems as well as in socio-economic development level, the overall direction of change tends to be more or less alike owing to the general nature of the underlying processes of globalisation and social change.

\section{References}

Alonso W. (1964), Location and land use. Toward a general theory of land rent. Cambridge (MA), Harvard University Press.

Berg L. van den, Drewet R., KlaAssen L.H., Rossi A., Vijverberg C.H.T. (1982), Urban Europe: a study of growth and decline, vol. 1. Oxford, Pergamon.

BERRY B.J.L. (1973), Growth centers in the American urban system, vol. 1. Community development and regional growth in the Sixties and Seventies. Cambridge (MA), Ballinger.

BERRY B.J.L. (1978), The counterurbanization process: how general? In: HANSEN N.M. (ed.), Human settlement systems. International perspectives on structure, change and public policy, pp. 25-49. Cambridge (MA), Ballinger.

Berry B.J.L., Horton F.E. (1970), Geographical perspectives on urban systems. Englewood Cliffs (NJ), Prentice-Hall.

BORCHERT J. (1967), American metropolitan evolution. In: Geographical Review, 57, 3, pp. 301332.

BouRne L.S. (1975), Urban systems: strategies for regulation. A comparison of policies in Great Britain, Sweden, Australia and Canada. Oxford, Clarendon. 
BRunet R. (1989), Les villes “europeennes" [The "European” cities]. Paris, La Documentation Francaise.

Burger M., MeIJers E. (2012), Form follows function? Linking morphological and functional polycentricity. In: Urban Studies, 49, 5, pp. 1127-1149.

Castells M. $\left(2000^{2}\right)$, The rise of the network society. The information age: economy, society and culture. Cambridge (MA) - Oxford (UK), Blackwell.

Cattan N., Pumain D., Rozenblat C., Saint-Julien T. (1994), Le systeme des villes europeennes [The European city system]. Cole - Villes, Anthropos.

Couch Ch., Leontidou L., Petchel-Held G. (2007), Urban sprawl in Europe. Landscapes, land use change and policy. Oxford, Blackwell.

Czyż T. (1998), Polaryzacja rozwoju regionalnego w okresie transformacji społeczno-ekonomicznej w Polsce [Polarisation in regional development in the context of socio-economic transformation in Poland]. In: ParyseK J., Rogacki H. (eds.), Przemiany społeczno-gospodarcze Polski lat dziewięćdziesiątych, pp. 47-63. Poznań, Bogucki.

Di Lello O., Rozenblat C. (2014), Les reseaux de firmes multinationales dans les villes D'Europe centre-orientale [The networks of international enterprises in the cities of East-Central Europe]. In: Cybergeo: European Journal of Geography, 678.

Domański B. (2008), Rozwój polskich metropolii a regiony peryferyjne. Bezpowrotna separacja czy współzależność rozwoju? [The development of Polish metropolises and peripheric regions. Irrevocable separation or interdependence of development?]. In: Studia KPZK PAN, 120, pp. 135-143.

DövenYI Z., KovÁcs A. (2006), Budapest: the post-socialist metropolitan periphery between "catching-up" and individual development path. In: European Spatial Research and Policy, 13, 2, pp. 23-41.

Duncan O.D., Scott R.W., Lieberson S., Duncan B., Winsborough H.H. (1960), Metropolis and region. Baltimore, The Johns Hopkins Press.

EBERHARDT P. (1970), Rola wielkich miast w strukturze regionalnej powiązań przestrzennych w Polsce [The role of large cities in the regional structure of spatial relationships in Poland]. In: Biuletyn KPZK PAN, 58, pp. 3-170.

ENYEDI Gy. (1994), Der Wandel postsozialistischer Städte [The change of post-Socialist cities]. In: Mitteilungen der Österreichischen Geographischen Gesellschaft, 136, S. 53-70.

European Spatial Planning Observation Network (ESPON 1.1.1) (ed.) (2004), The role, specific situation and potentials of urban areas as nodes in a polycentric development. Final Report. Luxembourg, European Communities.

European Spatial Planning Observation Network (ESPON 1.4.3) (ed.) (2007), Study on urban functions. Final Report. Luxembourg, European Communities.

European Spatial Planning Observation Network (ESPON FOCI) (ed.) (2010), Future orientation of cities. Final Report. Luxembourg, European Communities.

European Spatial Planning Observation Network (ESPON ET 2050) (ed.) (2012), Territorial scenarios and visions for Europe. Interim Report. Luxembourg, The ESPON Coordination Unit.

European Spatial Planning Observation Network (ESPON) (ed.) (2013), New evidence on smart, sustainable and inclusive territories. Luxembourg, The ESPON Coordination Unit.

Fassmann H. (ed.) (1997), Die Rückkehr der Regionen. Beiträge zur regionalen Transformation Ostmitteleuropas [Return of the regions. Contributions to the regional transformation of East-Central Europe]. Wien, Verlag der Österreichischen Akademie der Wissenschaften.

GÁL Z. (2015), Development of international financial centres in Central and Eastern Europe during transition period and crisis. The case of Budapest. In: Studia Regionalne i Lokalne, 2, 60, pp. 53-80. 
Gorzelak G., Smętкowski M. (2005), Metropolia i jej region w gospodarce informacyjnej [The metropolis and its region in the transformation society]. Warszawa, Scholar.

Gras N.B.S. (1922), The development of metropolitan economy in Europe and America. In: American Historical Review, 27, 4, pp. 695-708.

GrochowsKi M. (2012), The local dimension in the development of urban-rural regions. In: KorCELli P., Grochowski M., Kozubek E., Korcelli-Olejniczak E., Werner P. (eds.), Development of urban-rural regions: from European to local perspective, pp. 61-126. Warszawa, Institute of Geography and Spatial Organization, Polish Academy of Sciences.

Groth N.B. (ed.) (2001), Cities and networking: the Baltic Sea Region (= Reports, 8). Horsholm, Danish Centre for Forest, Landscape and Planning.

Groth N.B., Alvheim S. (2001), The role of universities in developing the Baltic Sea Region. In: Urban Systems and Urban Networking in the Baltic Sea Region. Horsholm, Danish Forest and Landscape Research Institute.

GUTRY-KorYCKA M. (ed.) (2005), Urban sprawl: the case of Warsaw. Warsaw, University of Warsaw. HaLl P. (1990), Europe after 1992. In: Urban challenges. Report to the Commission on Metropolitan Problems, pp. 179-185. Stockholm, Statens offentliga utredningar.

Hall P. (1993), Forces shaping urban Europe. In: Urban Studies, 30, 6, pp. 883-898.

Hall P., Hay P. (1980), Growth centres in the European urban system. London, Heinemann.

HeffNer K. (2008), Funkcjonowanie małych miast w systemie osadniczym Polski w perspektywie 2033 [The function of small towns in the Polish settlement system in a perspective up to 2033]. In: Saganowski K., Zagrzejewska-Fiedorowics M., Żuber P. (eds.), Ekspertyzy do Koncepcji Przestrzennego Zagospodarowania Kraju 2008-2033, pp. 281-333. Warszwa, Ministerstwo Rozwoju Regionalnego.

HefFNER K. (2014), Directions of changes in the development of Polish rural areas - entering into European rural space. In: KAMińsKa W., HeFFnER K. (eds.), Rural development and EU cohesion policy, pp. 10-31. Warsaw, Polish Academy of Sciences Committee for Spatial Economy and Regional Planning.

HIRT S. A. (2012), Iron curtains: gates, suburbs and privatization of space in the post-socialist city. London, Wiley - Blackwell

Horváth Gy. (2009). Cohesion differences in Eastern and Central Europe = inequalities of regional research area (= Discussion Papers, 72). Pécs, Centre for Regional Studies of Hungarian Academy of Science.

IANoş I. (2002), The maturing of the Romanian urban system. In: GEYer H.S. (ed.), International handbook of urban systems, pp. 295-327. Cheltenham, Edward Elgar.

Klasik A., BinieCKi J., OCHOJSKI A. (2014), Metropolitalny foresight strategiczny. Metodologia i studium przypadku [Metropolitan strategic foresight. Methodology and case study]. In: Studia KPZK PAN, 160, pp. 3-208.

Knox P.L., TAYlor P.J. (eds.) (1995), World cities in a world system. Cambridge, Cambridge University Press.

Komornicki T., SiŁKa P. (eds.) (2011), Functional linkages between Polish metropolises. Warsaw, Polish Academy of Sciences Committee for Spatial Economy and Regional Planning.

Korcelli P. (1990), Eastern-central Europe. In: Urban challenges. Report to the Commission on Metropolitan Problems. Stockholm, Statens offentliga utredningar, pp. 159-177.

Korcelli P. (2005), The urban system of Poland. In: Built Environment, 32, 2, pp. 133-142.

Korcelli-Olejniczak E. (2012a), Marked by dynamics: Berlin and Warsaw in the process of Structural change. In: Derudder B., Hoyler M., Taylor P.J., Witlox F. (eds.), International handbook of globalization and world cities, pp. 517-521. Cheltenham (UK) - Northampton (MA), Edward Elgar. 
Korcelli-OlejnicZak E. (2012b), Region metropolitalny - pojęcie, struktura przestrzenna, dynamika [The metropolitan region - concept, spatial structure, dynamics] (= Prace Geograficzne, 235). Warszawa, Instytut Geografii i Przestrzennego Zagospodarowania PAN.

Korcelli-Olejniczak E., Korcelli P. (2015), On European metropolisation scenarios and the future course of metropolitan development in Poland. In: Geographia Polonica, 88, 1, pp. 107-121.

Kramer H., Kadi G. (2013), Polycentric city networks in Central-Eastern Europe. Existing concepts and empirical findings. In: Geographia Polonica, 86, 3, pp. 183-198.

KriśJANE Z . (2001), The urban system of Latvia. In: Urban Systems and Urban Networking in the Baltic Sea Region. Hornsholm, Danish Forest and Landscape Research Institute.

Lichtenberger E. (1994), Das metropolitane Zeitalter in Europa in West und Ost. In: Mitteilungen der Österreichischen Geographischen Gesellschaft, 136, S. 8-36.

Liszewski S. (2010), Kształtowanie miejskiej sieci osadniczej regionu metropolitalnego. Przykład metropolii łódzkiej. In: Ciok S., Migoń P. (eds.), Przekształcenia struktur Regionalnych, pp. 47-69. Wrocław, Uniwersytet Wrocławski.

Marszat T. (2008), Metropolitan processes in Central and Eastern Europe. In: European Spatial Research and Policy, 15, 2, pp. 27-37.

McKenzIE R.D. (1933), The metropolitan community. New York, McGraw-Hill.

Mendel M. (2013), Residential developers as actors of urban transformation in post-socialist Warsaw. PhD Thesis. Warsaw, Institute of Geography and Spatial Organization, Polish Academy of Sciences.

Ministry of Regional Development (ed.) (2012), Concept of Spatial Development of Poland (KPZK). Warsaw.

Musil J. (1993), Changing urban systems in post-communist societies in central Europe: analysis and prediction. In: Urban Studies, 30, 6, pp. 889-905.

Piorr A., Ravetz J., Tosics I. (eds.) (2011), Peri-urbanization in Europe: towards a European Policy to sustain urban-rural futures. University of Copenhagen, Academic Books Life Sciences.

Pred A. (1975), On the spatial structure of organizations ad the complexity of metropolitan interdependence. In: Papers of the Regional Science Association, 35, pp. 115-142.

Pumain D. (2000), Settlement systems in the evolution. In: Geografiska Annaler, 82 B, 2, pp. $73-87$.

SARZYŃSKI P. (2014), Katowice: zadymione i zielone [Katowice: smoky and green]. In: Portrety miast polskich. Polityka, 22, 2960, pp. 56-61.

Slavik V., Grac R., Klobucnik M., Kohutova K. (2011), Development of suburbanization of Slovakia on the example of the Bratislava region. In: MARszą T. (ed.), Urban region as engines of development, pp. 35-58. Warsaw, Polish Academy of Sciences Committee for Spatial Economy and Regional Planning.

SMĘTKOWSKI M. (2013), Rozwój regionów i polityka regionalna w krajach Europy Środkowo-Wschodniej w okresie transformacji i globalizacji [Regional development and regional policy in the countries of East-Central Europe in the context of transformation and globalisation]. Warszawa, Scholar.

SMĘTKowski M. (2015), The impact of the economic crisis on the metropolisation process in the capital cities of the CEE countries. In: Studia Regionalne i Lokalne, 2, 60, pp. 32-52.

Sокоц M. (2001), Central and Eastern Europe a decade after the fall of state socialism: regional dimensions of transformation processes. In: Regional Studies, 35, 7, pp. 645-655.

Stanilov K. (2003), Accesibility and land use: the case of suburban Seattle, 1960-1990. In: Regional Studies, 37, 8, pp. 783-794.

SyKora L., BouZARovsky S. (2011), Multiple transformations: conceptualizing the post-communist urban ransition. In: Urban Studies, 49, 1, pp. 43-60. 
Taylor P.J., Derudder B., Hoyler M., Witlox F. (2012), Advanced producer servicing networks of world cities. In: Derudder B., Hoyler M., TAylor P.J., Witlox F. (eds.), International handbook of globalization and world cities, pp. 135-145. Cheltenham (UK) - Northampton (MA), Edward Elgar.

TAMmaru T. (2000), Differential urbanization and primate city growth in soviet and post-soviet Estonia. In: Tijdschrift voor Economische en Sociale Geografie, 91, 1, pp. 20-30.

Tosics I. (2005), City development in Central and Eastern Europe since 1990: the impacts of internal forces. In: Hamilton F.E.I., Andrews K.D., Pichler-Milanovic (eds.), Transformation of cities in Central and Eastern Europe: towards globalization, pp. 44-78. Tokyo - New York, United Nations University.

TReuner P., Foucher M. (1994), Towards a new European space. Hannover, Akademie für Raumforschung und Landesplanung.

Vanagas J., Staniunas E. (2001), The Lithuanian urban system. In: Urban Systems and Urban Networking in the Baltic Sea Region. Horsholm, Danish Forest and Landscape Research Institute.

VAIShar A. (2008), Possibilities for the multifunctional development of rural regions in the Czech borderland. In: Europa XXI, 22, pp. 63-70.

WĘCŁAwowicz G. (2013), Transnational development strategy for the post-socialist cities of Central Europe. Warsaw, Institute of Geography and Spatial Organization, Polish Academy of Sciences.

Wittgenstein Centre for Demography and Global Human Capital, Vienna Institute of Demography, International Institute for Applied Systems Analysis (eds.) (2012), European Demographic Data Sheet. Vienna.

Wusten H. vAN DER (1993), Transformation processes in Eastern Europe: an introduction. In: Workshop on transformation processes in Eastern Europe. The Hague, Netherlands Organization for Scientific Research. 